\title{
Real estate as an investment asset
}

\author{
Tomáš Krulický ${ }^{1, *}$, Jakub Horák ${ }^{1}$ \\ ${ }^{1}$ University of Žilina, Faculty of Operation and Economics of Transport and Communications, \\ Univerzitná 1, 01026 Žilina, Slovak Republic
}

\begin{abstract}
The present text focuses on perceiving real estate property as an investment asset that generates a certain amount of revenue to its owner, assuming expected risk and the expected level of liquidity. The first step is to determine the open market value of the selected property, which represent the expected expenses of the investment costs incurred (taking into account other acquisition costs), then we determine the open market rent value, which is the expected return on the selected property, then identify possible business risk associated with the commercial use of real estate and finally, the liquidity of the entire investment is estimated. In conclusion, methods for evaluating investments are applied to assess the realization of the investment - acquisition of the selected real estate for commercial purposes, the estimated return time and the percentage of the return on investment is calculated of the paper.
\end{abstract}

Key words: open market value, investment evaluation methods, investment triangle

\section{Introduction}

Together with the general increase in the standard of living of the population, the available funds of the population of the country also increase and, therefore, household savings, according to the Czech Statistical Office in the second quarter of 2018, the saving rate reached $9.8 \%$ of revenues, which was a year-on-year increase of 0.4 p. p. Growth in household savings also raises the need to keep these funds in the future until the need for such funds is expected [1]. The manners in which households can free their funds are many , depending on the approach to risk, the required liquidity, the required return, the confidence of the population in individual financial products, and especially on the level of awareness of the household. One of the options households invest in is buying real estate [2]. Investment real estate can be defined as real estate that is purchased with the intent of its commercial use and not solving own housing needs, which are already solved in another way (by owning other property, for example) [3]. The aim of the contribution is to determine the return on investment real estate and the payback period of such investment.

\footnotetext{
* Coresponding author: krulicky@mail.vstecb.cz
} 


\subsection{Investment according to economic theory}

In terms of economic theory, an investment can be seen as sacrificing present value for future uncertainty, but with a reasonable amount of return reflecting, inter alia, the level of risk and liquidity [4]. In investment decision making, the investor usually decides according to the investment triangle shown in the figure below.

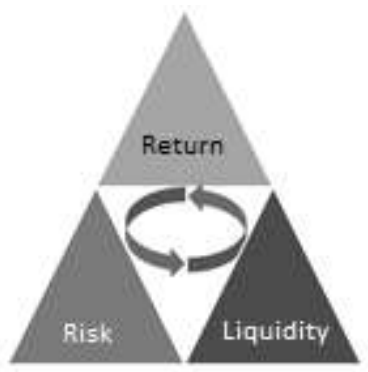

Fig. 1. Investment triangle

Source: Authors.

From the investment triangle, it is clear that the general investor is trying to decide on the investment according to three basic parameters, namely the expected return, the assumed risk and the liquidity of the investment. The relationship of all three variables is described by the behavior of the general investor - the general investor expects a higher return on higher risk, and vice versa [5]. Liquidity then expresses the ability to convert a given investment into a generally convertible asset (money) in a reasonable time at the usual price [6]. Each investor is specific and usually decides according to his / her relation to the assumed level of risk. It is clear that the three criteria do not represent a definitive list of criteria for investor investment decision making but serve as a demonstration of investment, and moreover, according to experience, these three characteristics are a typical feature of each investment [7]. Each investment is thus made with the vision of future return that may not only have the financial dimension but also the overall social dimension, the satisfaction of other needs and the wishes of the investor, etc. Correct investment should thus contribute to the future expansion of the investor's assets [8].

From the point of view of the development of the course during the lifespan of the investment activity, it is possible to distinguish the two basic phases of each investment:

- pre-investment phase,

- investment phase [9].

During the pre-investment phase, the investor collects and evaluates the available documents on the intended investment or investments, which are related to the first costs. It is not unusual for an investor to decide, after thorough analysis, to withdraw from the intended investment. In the construction sector, pre-project and project activities, geological surveys, costs of various permits, etc. are included in this stage. At this stage, the investment is abandoned either for objective reasons - for example, failure to grant approval for construction or for subjective reasons - investor strategy. It is clear that even if the investment is not realized, such costs are incurred by the investor, and it is not common for the investor to transfer the risk for an unrealized investment to third parties [10]. At this stage, households are looking for investment opportunities that they compare with each other and decide to realize some of the investments selected or a combination of them [11]. 
The investment phase is a realization phase, there is the actual investment and subsequent collection of return on investment. The investment phase is the longest of all phases, and the investor is under considerable risk. Unplanned completion of an investment at this stage occurs only exceptionally (depending on the riskiness of the investment) usually without the influence and will of the investor. Investors at this stage incur costs directly related to the operation of the investment [12].

\subsection{Real estate as an investment}

As mentioned above, investment real estate [13] is one of the options for the investment of household savings. Investment real estate is represented by real estate that can generate an expected return for their owner, most often real estate with a lower amount of floor area (approx. $60 \mathrm{~m} 2$ ) in larger residences intended for rental can be considered as investment real estate [14]. According to the authors, the demand for rental housing can be expected to be higher in this type of real estate, when they are presented as so-called start-ups for young or newly moved people from the countryside to cities who first choose the form of rent and then resort to buying their own housing.

Demand for the purchase of housing units between 2013 and 2018 enormously affected their price, housing price developments are monitored by the HB Index - see figure 2 . The HB index is based on realistic estimates of market prices of individual real estate properties that were financed through a bank. The HB index is constructed using a hedonic model that tracks up to 30 different real estate property parameters in real estate resolution into three groups, namely flats, family houses and land.

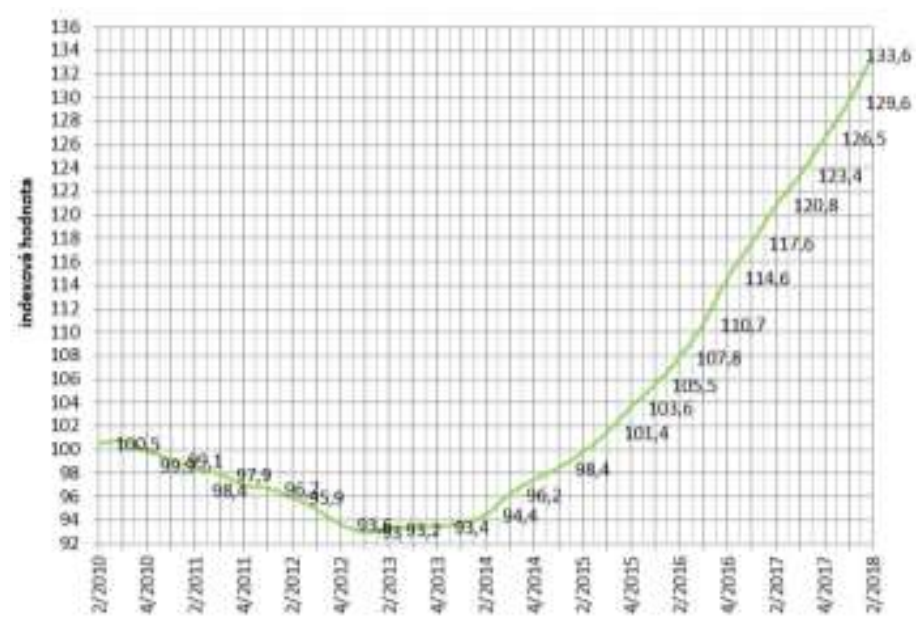

Fig. 2. HB INDEX - housing units

Source: [15].

In order to moderate the demand for the purchase of real estate, the Czech National Bank, with effect from 1 October 2018, tightened mortgage recommendation as one of the most popular tools for financing the purchase of real estate by Czech households, among the new recommendations are:

- The amount of income requirement - the amount of debt should not exceed the applicant's annual net income by 9 times.

- The applicant should spend a maximum of $45 \%$ of his monthly net income on debt repayment. 
- The ratio of the loan amount to the value of the pledged property - $90 \%$ maximum.

The tightening of the recommended conditions for mortgage applicants would thus have to limit the number of applicants, ie buyers, so it is to be expected that this segment of households will be forced to stay in rental housing and will increase the demand for this type of housing [16].

The aim of the paper is to determine the rate of return on investment in the selected real estate.

\section{Methodology}

The paper deals with the determination of the rate of return on investment of the selected real estate and its inclusion in the investment portfolio of the investor. For the purpose of achieving the aim of the contribution, the initial price of the selected real estate representing the initial investment cost (capital expenditure) taking into account the initial costs will be determined in the first step, the open market rent representing the expected investment income will be determined, then the estimated costs associated with the investment, while taking into account the vacancy rate, will be calculated and lastly, methods of investment evaluation will be applied in the final step.

The open market value will be determined by a comparative method, capturing a strong interaction between the market situation and the price of the selected real estate. The comparative method will be based on bid prices of comparable real estate where, according to the author's experience, the housing market is flexible and it can be assumed that the final price will not be too different from the bid price (by max. 9 percent), this difference will be subject to application of the coefficient of price source reduction. For comparison, 6 comparable real estate properties will be considered, which must meet the qualitative criteria for comparison - the similarity of the location, the correspondence of the structural system of the building, the constructionally technical condition, the size and layout solution. For all comparable properties, a coefficient reduction of the source price will be applied, amounting to $5 \%$ of the price obtained, expressing the buyer's ability to negotiate the final realization price. The open market value of an investment real estate will be determined as the average of the modified comparable objects and will be rounded to hundreds of thousands.

Furthermore, the open market rent will also be determined using a direct comparison method, based on offers for rent of comparable real estate. The rental market of housing units in the city of České Budějovice is very dynamic, there is a high rate of fluctuation of individual advertisements, the final rental price set in the lease will therefore be very close to the bid price and the landlord does not have a high motivation to discount the required rent. Open market rent will be determined as the average of 6 comparable properties advertised for rent. Comparable objects should be as close as possible to the investment asset in all criteria - location, technical condition, layout, etc., and rounded to hundreds. The determination of the expected income will take into account the occupancy rate and the costs associated with the operation of the investment. Determination of the occupancy rate will be made using the data from the actual survey of the offer market for rent. The survey will be carried out by monitoring the rental market for apartments in the city of České Budějovice for a period of one calendar month, the conclusion will be an evaluation of how many new offers during the monitoring period on the market have been added, how many were withdrawn from advertising, which will mean the average time from the publication of the advertisement until the time of its withdrawal (rental).

The qualified estimate will determine the additional costs associated with the investment, such as the one-off costs (open market real estate value, real estate acquisition tax, legal 
service, building adjustments) related to the acquisition of the investment, as well as the regular costs incurred during the lifespan of the investment (property tax, insurance, maintenance costs). The annual income from the investment will be determined as the difference between the open market annual rent, the expected costs during the investment and the expected vacancy rate (loss of rent).

Finally, methods for investment evaluation will be applied, taking into account investment risks, such as determining the return on investment and the payback period. The rate of return on investment will be expressed as a percentage of the expected annual investment income and estimated cost of ownership. The payback period will be determined in years as the ratio of the acquisition costs to that of the investment income.

Finally, the real estate earnings evaluation will be done using the discounted cash flow method in a two-phase variant, with the first phase taking only one year (2019), the second phase then include the period of 2020-infinity. For calculating the second phase, the Gordon model will be used, and the rate of profitability of the investment will be used as the required return rate.

\section{Results}

The chapter Results presents the results of the process described in the methodology section.

\subsection{Determination of the real estate open market value}

The open market value is the price that could be reached locally and on time between voluntary independent sellers and buyers, after proper marketing without considering extraordinary effects.

For comparison, the number of comparable objects is very important - but their number is often limited by the available amount on the local market in a given segment. Thus, the number of comparable objects is objectively limited from the top because the selected objects for comparison must meet strict quality criteria. It is therefore clear that the comparative method can only be applied in cases where a market with similar assets is sufficiently developed. A suitable representative of the investment real estate is the apartment unit constructed as $2+1$ with a total floor area of approx. $60 \mathrm{~m}^{2}$ located in a revitalized panel apartment building where the house and the apartment have undergone reconstruction, and the apartment is at least on the third floor above ground and is located in one of the apartment complex areas of České Budějovice.

In total, six comparable real estate properties were offered for sale at the Máj apartment complex area in the period from September 1, 2018 to September 30, 2018 were found. All comparable properties found are very close in qualitative terms and need not be corrected by correction coefficients, except for application of the reduction coefficient of the price source. This coefficient takes into account the difference between the estimated real estate sale price and the offer price. The reduction coefficient of the price source was determined for individual real estate properties after expert consideration, especially with regard to the negotiating possibility of the seller and the buyer with the final price. The selection of the coefficient value for each comparable property is given below. 
Table 1. Determination of the open market value of investment real estate property

Source: Authors.

\begin{tabular}{|c|c|c|c|c|c|}
\hline ID & Total price & Floor area & Layout & K1 & Adjusted price \\
\hline ID 1 & CZK 2,290,000 & $62 \mathrm{~m}^{2}$ & $2+1$ & 0.95 & CZK 2,175,500 \\
\hline ID 2 & CZK 1,850,000 & $64 \mathrm{~m}^{2}$ & $2+1$ & 0.95 & CZK 1,757,500 \\
\hline ID 3 & CZK 1,950,000 & $64 \mathrm{~m}^{2}$ & $2+1$ & 0.95 & CZK 1,852,500 \\
\hline ID 4 & CZK 2,270,000 & $63 \mathrm{~m}^{2}$ & $2+1$ & 0.95 & CZK 2,156,500 \\
\hline ID 5 & CZK 2,180,000 & $65 \mathrm{~m}^{2}$ & $2+1$ & 0.95 & CZK 2,071,000 \\
\hline ID 6 & CZK 1,840,000 & $67 \mathrm{~m}^{2}$ & $2+1$ & 0.95 & CZK 1,748,000 \\
\hline \multicolumn{5}{|c|}{ Average } & CZK 1,960,167 \\
\hline
\end{tabular}

The open market value of the average investment real estate was determined as the average of the adjusted price of comparable objects and amounts to CZK 1,960,167, after rounding to CZK 2,000,000.

\subsection{Determination of the open market rent}

The best use of the investment property is its rental. The property owner has basically two lease options - long-term (in the order of years) and short-term (days, weeks). The long-term lease is characterized by long-term cooperation and lease of a tenant, for the lessor, it means, depending on the choice of the tenant, lower lease management costs, unlike short-term rental, which for the lessor represents a higher administrative burden, but is offset by higher income. The following section will deal with determining the open market rent rates for longterm rentals.

For the purpose of determining the open market rent rates, a total of 6 comparable properties, which were advertised for lease in the period between 1 September 2018 and 30 September 2018, managed to meet these properties for their qualitative proximity to the pricesetting factors, it was not necessary to apply correction coefficients of difference.

Table 2. Determination of the open market rent

\begin{tabular}{|c|c|c|c|c|}
\hline ID & Total price & Floor area & Layout & Adjusted price \\
\hline ID 1 & CZK 8,000 & $64 \mathrm{~m}^{2}$ & $2+1$ & CZK 8,000 \\
\hline ID 2 & CZK 7,800 & $50 \mathrm{~m}^{2}$ & $2+1$ & CZK 7,800 \\
\hline ID 3 & CZK 8,300 & $50 \mathrm{~m}^{2}$ & $2+1$ & CZK 8,300 \\
\hline ID 4 & CZK 7,800 & $61 \mathrm{~m}^{2}$ & $2+1$ & CZK 7,800 \\
\hline ID 5 & CZK 7,500 & $50 \mathrm{~m}^{2}$ & $2+1$ & CZK 7,500 \\
\hline ID 6 & CZK 7,500 & $64 \mathrm{~m}^{2}$ & $2+1$ & CZK 7,500 \\
\hline \multicolumn{4}{|c|}{ Average } & CZK 7,817 \\
\hline
\end{tabular}

Source: Authors.

The open market monthly rent of the average real estate property ( $\mathrm{Pn}$ - monthly income) was determined as the average monthly rent of comparable objects and is CZK 7,817, after rounding 7,800 CZK, the annual rent (Annual income) can be determined from the formula 7,800 CZK * $12=$ CZK 93,600. Open market rents do not include fees associated with owning an apartment (contribution to the fund for repairs, services, etc.). 


\subsection{Estimated costs associated with the investment}

The estimated costs associated with the realization of the investment can be divided into two parts in terms of time spent, the first group being the costs incurred in connection with the acquisition of the investment and its immediate realization (acquisition costs); further costs are then spent during the main investment phase (operating costs). These costs do not express the value of the investor's time devoted to the acquisition and management of the investment.

Costs incurred for the acquisition and operation of the investment (one-off):

- $\quad$ Property acquisition (open market value) -

CZK 2,000,000

- Acquisition of immovable property tax (4\%) - CZK 80,000

- $\quad$ Legal service, counseling, etc. -

CZK 10,000

- $\quad$ Building adjustments -

CZK 10,000

- Total

CZK 2,100,000

Total capital expenditure ( $\mathrm{K} 0$ - acquisition cost) corresponds to the cost of acquisition of the investment and is estimated at CZK 2,100,000.

Costs incurred during property rental (recurring, annual):

- Property tax -

CZK 500

- Property + household insurance -

CZK 1,000

- Maintenance costs incl. reserves -

$\underline{\mathrm{CZK} 8,500}$

- Total

CZK 10,000

Regular annual costs $\left(\mathrm{N}_{\mathrm{r}}\right.$ - annual costs) associated with the operation of the property are estimated at CZK 10,000.

In determining the income from investment property it is also necessary to take into account the vacancy rate of the property. As a result of the change of the tenant, rents are lost when the apartment is vacant. From the survey conducted on offers for renting housing units in the whole city of České Budějovice during September 2018, most (approx. 75\%) of advertised apartments were rented within 1 month of publication of the advertisement. Loss of rent, or vacancy rate $\left(\mathrm{N}_{\mathrm{VN}}\right.$ - Costs, Loss of rent) will be assumed at $10 \%$ of the total annual rent.

The total revenue $(\mathrm{P})$ of the investment in the first year after taking into account the expected costs and the rent loss can be determined from the relationship:

$$
\begin{gathered}
\mathrm{P}_{\mathrm{r}}-\mathrm{N}_{\mathrm{r}}-\mathrm{N}_{\mathrm{VN}}=\mathrm{P} \\
\text { CZK 93,600-CZK 10,000-10\%=CZK 75,240 }
\end{gathered}
$$

\subsection{Investment evaluation}

The estimated incomes above are in absolute terms for the first year of rental, it can be assumed that the rational behavior of the lessor will make the income (rent) copy the development of inflation, otherwise a real decrease in rent will occur. Other compensation for landlords is the rise in property prices in the market.

Purchase of real estate is essentially an investment with an unlimited lifespan, when its lifetime is objectively limited by the life of the property itself from a structural point of view, but it can be very long, with adequate social demand (house maintenance costs).

\section{Return on investment}

The return of the selected investment (I) in percentage terms will be determined from the relationship:

$\left(\mathrm{P} / \mathrm{K}_{0}\right) * 100=\mathrm{I}$, therefore $(\mathrm{CZK} 75,240 / \mathrm{CZK} 2,100,000) * 100=3.58 \%$.

The return on the investment at unchanged input parameters is $3.58 \%$. 


\section{Payback time}

The payback period is the period for how long the expected revenue $(\mathrm{P})$ equals the capital expense K0. For the purposes of the present article, a simplified calculation will be used as follows: $2,100,000 / 75,240=27.9$.

The payback period of the investment 27.9 years from only rental income.

\section{Earnings evaluation of the property}

Property earnings evaluation methods can be applied to real estate evaluation when the property meets the requirements of going concern - unlimited lifespan, profit potential. The calculation will take into account year-on-year inflation, ie annual revenue and cost growth of the same amount (2\%), while the rate of return does not include inflation.

Table 3. Property earnings evaluation

\begin{tabular}{|c|c|c|}
\hline & $\mathbf{2 0 1 9}$ & $\mathbf{2 0 2 0 - x}$ \\
\hline Net annual income & CZK 75,240 & CZK 76,745 \\
\hline Rate of return & $3.58 \%$ & $3.58 \%$ \\
\hline Current value & CZK 72,638 & CZK 2,142,000 \\
\hline Evaluation & CZK 2,214,638 & -- \\
\hline
\end{tabular}

Source: Authors.

From the point of view of the unlimited lifespan of investment property, the use of other methods for investment evaluation is of no great significance for the investment evaluation, because in the case of a sufficiently long investment period, the investment will overcome the economic benefits and the investment will be recommended for realization.

\section{Conclusion}

The purpose of this contribution was to determine the rate of return on investment in the selected real estate, in this case an apartment intended for commercial use (long-term lease), which is the most frequent investment property. In the first step, the capital expenditure was determined as the sum of the open market value of the selected property determined using the comparative method, and the estimated costs associated with the acquisition were added to this amount. The annual income from this property was determined as the open market rent income, taking into account the estimated operating costs and the time when the rent was not collected (loss of rent). The return on selected investment property was $3.58 \%$, this profit did not include the expected inflation, and other implicit revenues in the form of a rise in property prices. If a comparison is made with other investment opportunities on the market, it is necessary to add $2 \%$ to the rate of return and the rate of inflation, the total return on the property is $5.58 \%$.

The aim of the paper was fulfilled.

The contribution could be followed by further research into the return on investment in real estate, their mutual comparison and the identification of the most profitable type of investment real estate property. 


\section{References}

1. Czech Statistical Office, Tiskové sděleni: Míra úspor domácností se zvýšila [online]. Available at: https://www.czso.cz/csu/czso/tiskove-sdeleni-mira-uspor-domacnosti-sezvysila

2. C. Eves, Residential Property Investment: Assessing Home Ownership Long Term Viability. International Conference on Construction and Real Estate Management, China, 631-634, (2012)

3. J. Jílek, J. Svobodová, Účetnictví podle mezinárodních standardů účetního výkaznictví. Praha: Grada, (2011)

4. F. Gao, A. Xi He, P. He, A theory of intermediated investment with hyperbolic discounting investors. Journal of Economic Theory, 177, 70-100, (2018)

5. E. Bikas, V. Saponaite, M. Tvaronavičienè, Behavior of the Lithuanian investors at the period of economic growth. Entrepreneurship and Sustainability Issues, 6(1), 44-59, (2018)

6. M. Bade, H. Hirth, Liquidity cost vs. real investment efficiency. Journal of Financial Markets, 28, 70-90, (2016)

7. M. A. S. Bradbury, T. Hens, S. Zeisberger, How persistent are the effects of experience sampling on investor behavior? Journal of Banking \& Finance, 98, 61-79, (2019)

8. S. Sung, H. Cho, D. Ryu, The Behavior of an Institutional Investor with Arbitrage Opportunities and Liquidity Risk. Emerging Markets Finance and Trade, 55(1), 1-12, (2018)

9. J. Fotr, I. Souček, Podnikatelský záměr a investiční rozhodování. Praha: Grada Publishing, (2005)

10. J. Janeková, J. Fabianová, D. Onofrejová, E. Puškaš, M. Buša, Implementation of deviation analysis method in the utilisation phase of the investment project: a case study. Polish Journal of Management Studies, 15(1), 99-109, (2017)

11. C. Giordano, M. Marinucci, A. Silvestrini, The macro determinants of firms' and households' investment: Evidence from Italy. Economic Modelling, in press (2018)

12. Y. Chen, M. Chiang, C. Weng, Are investors always compensated for information risk? Evidence from Chinese reverse-merger firms. Review of Quantitative Finance and Accounting, 1-38, (2018)

13. F. Prizzon, A. Cullino, Investment Property in Rental: Profitability and Risk Analysis. New Metropolitan Perspectives. International Symposium on New Metropolitan Perspectives, 499-506, (2019)

14. N. Turner, M. Thomas, Property market indices and lease structures - the impact on investment return delivery in the UK and Germany: Part I. Journal of Property Investment \& Finance, 19(2), 175-194, (2001)

15. Mortgage Bank, HB index: Nemovitosti dále zdražují i přes klesající poptávku [online]. Available at: https://www.hypotecnibanka.cz/o-bance/pro-media/hb-index/nemovitostidale-zdrazuji-i-pres-klesajici-poptavk/ (2018)

16. Aktuálně.cz, Hypotéky čeká př́sné omezeni: ČNB zavádi dvě nová opatření, vlastní bydleni bude méně dostupné [online]. Available at: https://zpravy.aktualne.cz/finance/hypoteky-ceka-prisne-omezeni-cnb-zavadi-dvanove-stropy-muze/r 9f6317e66e1511e892700cc47ab5f122/ (2018) 